\title{
Numerical investigation of lambda-value prechamber ignition in heavy duty natural gas engine
}

\begin{abstract}
Turbulent Jet Ignition systems are mainly dedicated to the combustion of lean mixtures of natural gas in heavy duty engines. The use of such a system in combination with lean mixtures leads to an increase in its overall efficiency. The article presents simulation analyzes of the impact of the air excess coefficient occurring in prechamber on the combustion process: combustion indicators and emission indicators. Tests on a single-cylinder engine with a displacement of about $4 \mathrm{dm}^{3}$ at medium mixture (IMEP $\left.=1.0 \mathrm{MPa}\right)$ were carried out using the AVL Fire software. It was found that the incineration of global lean mixtures $(\lambda=2)$ is effective when initiating this process (in the prechamber) with a charge of a stoichiometric composition. A strong relationship was found between the thermodynamic indicators in both prechamber and main chamber and the air excess coefficient initiating combustion.
\end{abstract}

Key words: Turbulent Jet Ignition, combustion thermodynamics, combustion process indicators, numerical simulation

\section{Introduction}

Turbulent Jet Ignition (TJI) systems are mainly used in engines running on lean mixtures. The solutions of the TJI system analyzed by Attard [3, 4] obtained an indicated thermal efficiency of $42 \%$ when burning lean mixtures. They find use mainly in large heavy duty (HD) engines [15]. Solutions for TJI systems were presented by Alvarez et al. [1]. He pointed to the possibility of increasing the range of lean mixtures to $\lambda=2.5$, however, while using hydrogen as fuel for the prechamber (PC); petrol was fed to the main chamber (MC).

However, research on their possible applications in engines with small displacement is noted increasingly more often $[4,12,17]$. Road tests in the Real Driving Emissions (RDE) test were presented by Roso et al. [18] with the use of an engine with the PCIS (Pre Chamber Ignition System) with an air excess coefficient equal to $\lambda=1.4$. Similar scientific papers with the use of internal combustion engines with the TJI system in hybrid drives and Range Extender (REX) were also published by Sens et al. [19].

Most TJI solutions use the stoichiometric compound value in the prechamber [5]. The latest solution is the socalled Dual Mode TJI (DM-TJI) - a system based on controlling the amount of recirculated exhaust gas in the prechamber [2]. The use of an additional valve supplying air to the prechamber allows for the proportion of recirculated exhaust gas to be increased to $40 \%$.

In the research conducted by da Costa et al. [9] on the AVL 5496 engine $\left(0.454 \mathrm{dm}^{3}\right)$ different values of the air excess coefficient in the prechamber $(\lambda=1.0-1.6)$ were used, however the same values were used in the main chamber. The maximum combustion indicator values were obtained for $\lambda$ in the range of 1.3-1.4.

Korb et al. used the large global air excess coefficient [13] in simulations and experimental research. It was found that turbulence in the prechamber and use of the Miller cycle during the air intake have great significance in the combustion process.

TJI systems are made with passive prechambers (without fuel supply). However, the latest research confirms that depending on their design, it is possible to burn lean mixtures up to the value of $\lambda=1.6[16]$ or $\lambda=1.8$ [6].
A literature review reveals that research on ultra-lean mixtures is the subject of high research interest, however, no information can be found on the impact of the air excess coefficient value in the prechamber on combustion process indicators.

\section{Research aim}

The aim of the research was to determine the best values of the air excess coefficient in the prechamber in the vicinity of $\lambda=1$ leading to favorable thermodynamic and ecological impact for the combustion of ultra-lean mixtures $(\lambda=2)$.

Research was focused on obtaining both one- and twodimensional information on the global and local combustion process indicators.

The article seeks to answer the question of what the value of the air excess ratio during the start of the combustion process should be, in order to obtain the best thermodynamic indicators of the combustion process.

\section{Method}

\subsection{Research object}

The most widespread use of TJI combustion system can be found in HD engines. For this reason, an object similar in construction parameters to the supercharged GS6R2PTK [14] engine from Mitsubishi was selected for analysis. It is an engine for Power Generation and Cogeneration applications. The maximum power output among the engine family (GS16R2-PTK - 16 cylinder engine) is 1.5 MW at $1500 \mathrm{rpm}$. The engine is powered with lean natural gas mixtures and operates in the Miller cycle (Table 1).

Table 1. Characteristics of the GS16R2-PTK engine [14]

\begin{tabular}{|l|c|c|}
\hline Parameter & Unit & Value \\
\hline Type & - & 4-cycle, intercooled \\
\hline Aspiration & - & turbocharged \\
\hline Number of cylinders & - & 6 \\
\hline Bore $\times$ stroke & $\mathrm{mm}$ & $170 \times 180$ \\
\hline Displacement & $\mathrm{dm}^{3}$ & 24.52 \\
\hline Combustion system & - & prechamber, spark ignited \\
\hline Fuel & - & natural gas \\
\hline $\begin{array}{l}\text { Continuous power rating } \\
\text { output }(50 \mathrm{~Hz} 1500 \mathrm{rpm})\end{array}$ & $\mathrm{kW}$ & 363 \\
\hline
\end{tabular}


In accordance with the above parameters, combustion system consisting of a prechamber with 7 holes $(\phi=1.8$ $\mathrm{mm}$ and $1=3.9 \mathrm{~mm}$ ) arranged symmetrically connected to the main chamber and having dimensions as shown in Fig. 1 was adopted for combustion tests. The combustion chamber is an original design modeled in the analyzed natural gas engine (which is the result of the lack of access to the original solution).

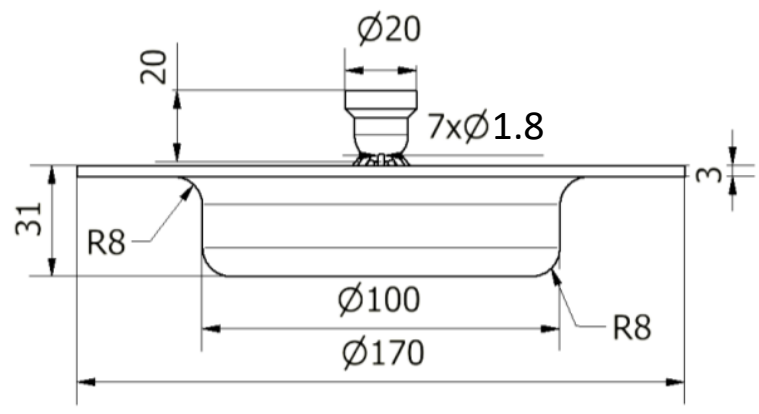

Fig. 1. Model of the engine combustion chamber powered by natural gas used for testing

The volume of one cylinder $\left(\mathrm{V}_{\text {cyl }}\right)$ was $4.085 \mathrm{dm}^{3}$. Based on the adopted dimensions of the combustion chamber its volume was determined $-\mathrm{V}_{\mathrm{CH}}=298.08 \mathrm{~cm}^{3}$. The figure indicates the volume of the preliminary chamber $-\mathrm{V}_{\mathrm{PC}}=$ $=11.86 \mathrm{~cm}^{3}$. For these adopted values, the volume of the prechamber equals $3.98 \%$ of the combustion chamber volume. The compression ratio of such a model combustion system is $\varepsilon=14.79$.

\subsection{Simulation method}

The combustion process was based on the ECFM-3Z (Extended Coherent Flame Model-three Zone) [8]. This model is used in GDI engines with a large proportion of recirculated exhaust gas [10], as well as in gas-fueled engines [11].

The ECFM model is derived from the classic combustion model based on CFM flame density (Coherent Flame Model). The main assumption is that the fresh mixture does not contain recirculated flue gas. Due to the heterogeneity of the air-fuel mixture composition in the ECFM model, the so-called fuel and oxygen traces were introduced for more accurate local calculations of the intake gas composition. The gas enthalpy equation was defined in a similar way, enabling accurate assessment of temperature. As a consequence, it is possible to assess the local laminar flame speed $[10,11]$.

According to the division of the ECFM-3Z zone (Fig. 2), each calculation cell is divided into three mixing zones: mixed fuel zone (letter F), zone containing fuel mixture, air and EGR (letter M) and unmixed air zone + EGR (letter A).

In the ECFM model, we solve a transport equation for the average quantities of chemical species of $\mathrm{O}_{2}, \mathrm{~N}_{2}, \mathrm{CO}_{2}$, $\mathrm{CO}, \mathrm{H}_{2}, \mathrm{H}_{2} \mathrm{O}, \mathrm{O}, \mathrm{H}, \mathrm{N}$, and $\mathrm{OH}$. This equation is classically denoted as:

$$
\frac{\partial \bar{\rho} \widetilde{\mathrm{y}}_{\mathrm{x}}}{\partial \mathrm{t}}+\frac{\partial \bar{\rho} \widetilde{\mathrm{u}}_{\mathrm{i}} \widetilde{\mathrm{y}}_{\mathrm{X}}}{\partial \mathrm{x}_{\mathrm{i}}}-\frac{\partial}{\partial \mathrm{x}_{\mathrm{i}}}\left(\left(\frac{\mu}{\mathrm{Sc}}+\frac{\mu_{\mathrm{t}}}{S \mathrm{c}_{\mathrm{t}}}\right) \frac{\partial \widetilde{\mathrm{y}}_{\mathrm{x}}}{\partial \mathrm{x}_{\mathrm{i}}}\right)=\overline{\dot{\omega}}_{\mathrm{X}}
$$

where $\overline{\dot{\omega}_{\mathrm{x}}}$ is the combustion source term and $\tilde{y}_{\mathrm{x}}$ is the averaged mass fraction of species $\alpha$.

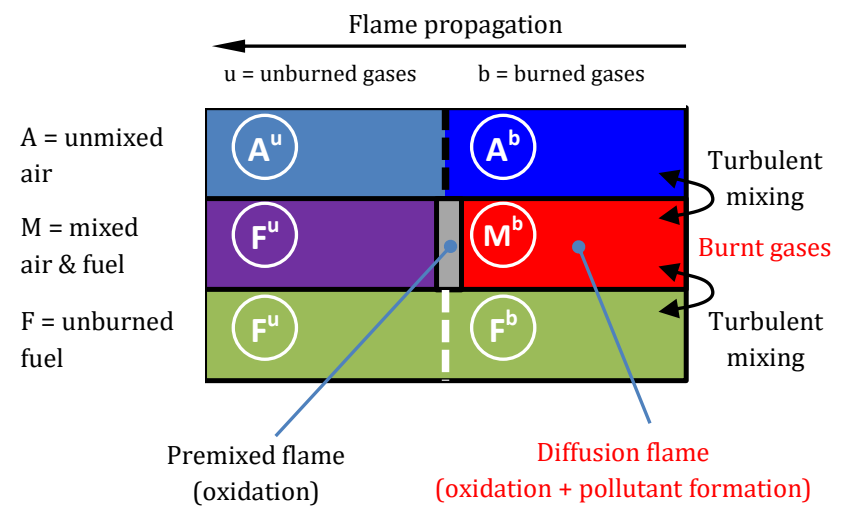

Fig. 2. Schematic of the ECFM-3Z model computational cell [7]

The fuel is divided in two parts: the fuel present in the fresh gases $\tilde{y}_{\mathrm{Fu}}^{\mathrm{u}}$, and the fuel present in the burnt gases $\tilde{y}_{\mathrm{Fu}}^{\mathrm{b}}$ :

$$
\tilde{y}_{\mathrm{Fu}}^{\mathrm{u}}=\frac{\overline{\mathrm{m}}_{\mathrm{Fu}}^{\mathrm{u}}}{\overline{\mathrm{m}}}=\frac{\overline{\mathrm{m}}_{\mathrm{Fu}}^{\mathrm{u}} / \mathrm{V}}{\overline{\mathrm{m}} / \mathrm{V}}=\frac{\bar{\rho}_{\mathrm{Fu}}^{\mathrm{u}}}{\bar{\rho}}
$$

and

$$
\tilde{\mathrm{y}}_{\mathrm{Fu}}^{\mathrm{b}}=\frac{\overline{\mathrm{m}}_{\mathrm{Fu}}^{\mathrm{b}}}{\overline{\mathrm{m}}}=\frac{\overline{\mathrm{m}}_{\mathrm{Fu}}^{\mathrm{b}} / \mathrm{V}}{\overline{\mathrm{m}} / \mathrm{V}}=\frac{\bar{\rho}_{\mathrm{Fu}}^{\mathrm{b}}}{\bar{\rho}}
$$

where $\tilde{y}_{\mathrm{Fu}}=\tilde{y}_{\mathrm{Fu}}^{\mathrm{u}}+\tilde{y}_{\mathrm{Fu}}^{\mathrm{b}}$ is the mean fuel mass fraction in the computational cell. $\overline{\mathrm{m}}_{\mathrm{Fu}}^{\mathrm{u}}$ (or $\overline{\mathrm{m}}_{\mathrm{Fu}}^{\mathrm{b}}$ ) is the mass of the fuel contained in the fresh gases (resp. burnt gases). A transport equation is used to compute $\tilde{y}_{\mathrm{Fu}}^{\mathrm{u}}$ :

$$
\frac{\partial \bar{\rho} \widetilde{\mathrm{y}}_{\mathrm{Fu}}^{\mathrm{u}}}{\partial \mathrm{t}}+\frac{\partial \bar{\rho} \widetilde{\mathrm{u}}_{\mathrm{i}} \widetilde{\mathrm{y}}_{\mathrm{Fu}}^{\mathrm{u}}}{\partial \mathrm{x}_{\mathrm{i}}}-\frac{\partial}{\partial \mathrm{x}_{\mathrm{i}}}\left(\left(\frac{\mu}{\mathrm{Sc}}+\frac{\mu_{\mathrm{t}}}{S \mathrm{c}_{\mathrm{t}}}\right) \frac{\partial \widetilde{\mathrm{y}}_{\mathrm{Fu}}^{\mathrm{u}}}{\partial \mathrm{x}_{\mathrm{i}}}\right)=\bar{\rho} \tilde{\hat{S}}_{\mathrm{Fu}}^{\mathrm{u}}+\overline{\dot{\omega}}_{\mathrm{Fu}}^{\mathrm{u}}
$$

where $\tilde{\dot{S}}_{\mathrm{Fu}}^{\mathrm{u}}$ is the source term quantifying the fuel evaporation in fresh gases. $\overline{\dot{\omega}}_{\mathrm{Fu}}^{\mathrm{u}}$ is a source term taking autoignition, premixed flame and mixing between mixed unburned and mixed burnt areas into account.

\subsection{Simulation conditions}

The analysis of the air excess ratio impact in the prechamber on the combustion process was carried out at engine speed of $\mathrm{n}=1500 \mathrm{rpm}$ at an average load (IMEP $=$ $=1.08 \mathrm{MPa}$ ).

The fuel dose fed into the cylinder is divided in such a way that a lean homogeneous mixture with $\lambda$ value close to 2 is supplied to the main chamber. A different dose of fuel $\mathrm{q}_{\mathrm{o} \_\mathrm{PC}}$ is supplied to the prechamber in such a way that the sum of both fuel doses is constant $\left(\lambda_{\mathrm{ALL}}=\right.$ const $)$ :

$$
\lambda_{\mathrm{ALL}}=\frac{\mathrm{m}_{\mathrm{air}}}{\left(\mathrm{q}_{\mathrm{o} \_\mathrm{MC}}+\mathrm{q}_{\mathrm{o} \_\mathrm{PC}}\right) \cdot 17.2}
$$

The test conditions were set in such a way that the total fuel dose generated an air excess coefficient value of 2 . This means that increasing the prechamber dose should lead to an increase the air excess ratio in the MC. Table 2 summarizes the initial simulation values. 
Table 2. Simulation test conditions (initial condition)

\begin{tabular}{|c|c|c|c|c|c|c|c|}
\hline $\begin{array}{l}\text { Para- } \\
\text { meter }\end{array}$ & Unit & \multicolumn{6}{|c|}{ Value } \\
\hline$\lambda_{\mathrm{ALL}}$ & - & \multicolumn{6}{|c|}{2} \\
\hline $\mathrm{P}_{\text {air }}$ & $\mathrm{MPa}$ & \multicolumn{6}{|c|}{0.2} \\
\hline $\mathrm{q}_{\mathrm{o} \_\mathrm{MC}}$ & $\mathrm{mg}$ & 222.0 & 221.8 & 221.6 & 221.3 & 221.1 & 220.8 \\
\hline$\lambda_{\mathrm{MC}}$ & - & 2.023 & 2.027 & 2.030 & 2.036 & 2.039 & 2.045 \\
\hline $\mathrm{q}_{\mathrm{o} \_\mathrm{PC}}$ & $\mathrm{mg}$ & 1.3 & 1.5 & 1.7 & 2.0 & 2.2 & 2.5 \\
\hline$\lambda_{\text {ign_PC }}$ & - & 1.102 & 1.038 & 0.984 & 0.919 & 0.882 & 0.835 \\
\hline IVC & $\operatorname{deg}$ & \multicolumn{6}{|c|}{$500 \mathrm{deg}$ (Miller cycle) } \\
\hline \multicolumn{2}{|c|}{ Temperature } & \multicolumn{6}{|c|}{$350 \mathrm{~K}$} \\
\hline \multicolumn{2}{|c|}{ TKE } & \multicolumn{6}{|c|}{$20 \mathrm{~m}^{2} / \mathrm{s}^{2}$} \\
\hline \multicolumn{2}{|c|}{ Turb. length scale } & \multicolumn{6}{|c|}{$0.003 \mathrm{~m}$} \\
\hline \multicolumn{2}{|c|}{ Turb. diss. rate } & \multicolumn{6}{|c|}{$4899 \mathrm{~m}^{2} / \mathrm{s}^{3}$} \\
\hline \multicolumn{2}{|c|}{$\begin{array}{l}\text { Combustion } \\
\text { model }\end{array}$} & \multicolumn{6}{|c|}{ Coherent Flame Model; ECFM-3Z } \\
\hline \multicolumn{2}{|c|}{ Emission model } & \multicolumn{6}{|c|}{ Extended Zeldovicz (NO), kinetic model (Soot) } \\
\hline
\end{tabular}

In the conducted research, the most interesting aspect were the conditions present in the pre-chamber. The compression stroke (early closing of the intake valve) and the combustion stroke were modeled. For this reason, modeling of valve movement as well as inlet and outlet channels was not performed.

Due to the above, the boundary conditions are limited only to the main combustion chamber and the prechamber (Table 3).

Table 3. Boundary conditions

\begin{tabular}{|l|c|c|}
\hline Parameter & Unit & Value \\
\hline Head & $\mathrm{T}[\mathrm{K}]$ & 550 \\
\hline Liner & $\mathrm{T}[\mathrm{K}]$ & 475 \\
\hline Piston & $\mathrm{T}[\mathrm{K}]$ & 525 \\
\hline Prechamber & $\mathrm{T}[\mathrm{K}]$ & 575 \\
\hline
\end{tabular}

\subsection{Method}

Research on thermodynamic processes was carried out using the AVL FIRE 2019 R2 software. The combustion chamber model was made as a polymesh mesh with a variable number of cells (min: 32805; max: 80057). The computational grid was compacted around the prechamber, assuming a minimum cell length of $0.5 \mathrm{~mm}$ (Fig. 3a). The optimization of the computational domain was not carried out, however, it was compacted for the prechamber. The mesh was generated using the Fame Engine Plus module of the AVL FIRE program. A visualization of the combustion chamber used for the analysis is shown in Fig. $3 b$. a)

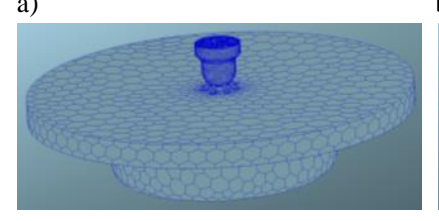

b)

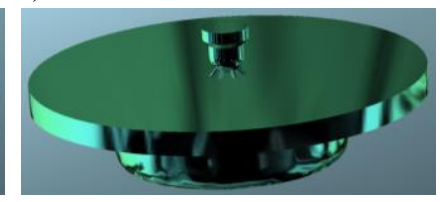

Fig. 3. Combustion chamber: a) mesh with compaction of the prechamber, b) shape of the combustion chamber

\section{Analysis of thermodynamic quantities of the combustion process}

\subsection{Ignition conditions in the PC}

The analysis of ignition conditions in the prechamber begun by determining the value of $\lambda_{\mathrm{PC}_{\mathrm{ign}}}$ after assuming a few determined values of the fuel dose fed to the pre- chamber $-\mathrm{q}_{\mathrm{o} \_\mathrm{PC}}$. The values of $\lambda_{\mathrm{PC} \_ \text {ign }}$ were determined on this basis in accordance with Fig. 4.

In this research, AVL FIRE was used to adopt a methodology in which engine TDC during combustion is reached at $720 \mathrm{deg}$ on the crankshaft. Although it is a 360 deg shift, it does not change the engine operating conditions.

Prechamber gas injection was performed $\left(\alpha_{\text {inj_PC }}=510\right.$ $540 \mathrm{CA}$ ) in the early phase after closing the intake valve $(\mathrm{IVC}=500 \mathrm{deg})$. The ignition of the mixture in the prechamber was set at $695 \mathrm{deg}$ CA.

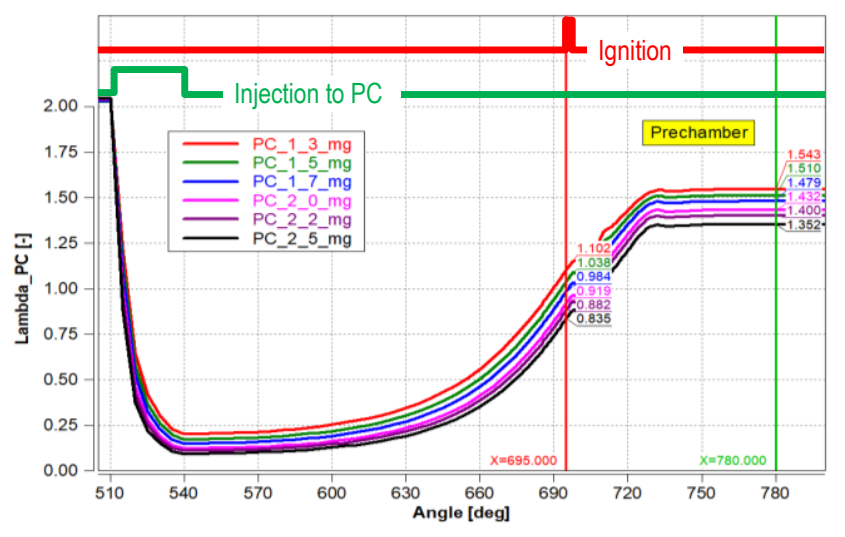

Fig. 4. Prechamber fuel dose values and the determined $\lambda$ values during ignition in the prechamber

The mean value of the air excess coefficient in the combustion chamber is reduced proportionally to the increasing fuel dose value $\mathrm{q}_{\mathrm{o} \_P C}$. When the combustion process begins the $\lambda$ value is not constant - it increases as a result of mass flow from the main chamber to the prechamber. The changes in $\lambda_{\text {PC_ign }}$ were determined based on the selection of the $\mathrm{q}_{\mathrm{o} \_\mathrm{PC}}$ value. These trends are shown in Fig. 5. It can be seen that the adopted strategies for changing the air excess coefficient for (global) combustion of lean mixtures maintained it around $\lambda=1$.

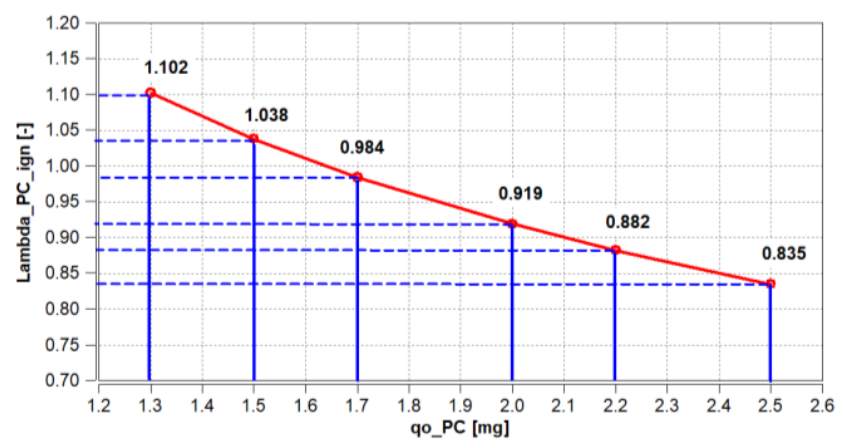

Fig. 5. The adopted initial dose values for prechamber and the corresponding values of the air excess coefficient during ignition

Gas injection at high doses in the early phase of the piston movement was found to cause the flow of this mixture to the main chamber (Fig. 6-2.5 mg). During the compression stroke, this tendency is not observed only at the smallest values of the dose fed into the cylinder. In the vicinity of the ignition angle in prechamber there is still no homogeneous combustible mixture. However, with $\mathrm{q}_{\mathrm{o}}$ values in the range of 
1.3 to 1.7 , the quality of the mixture most closely resembles homogeneous. The symmetry of the openings connecting the $\mathrm{PC}$ and $\mathrm{MC}$ causes the charge from the main chamber to reach the center of the prechamber. The use of the k-zeta-f model results in a rich mixture being formed in the vicinity of the prechamber walls.

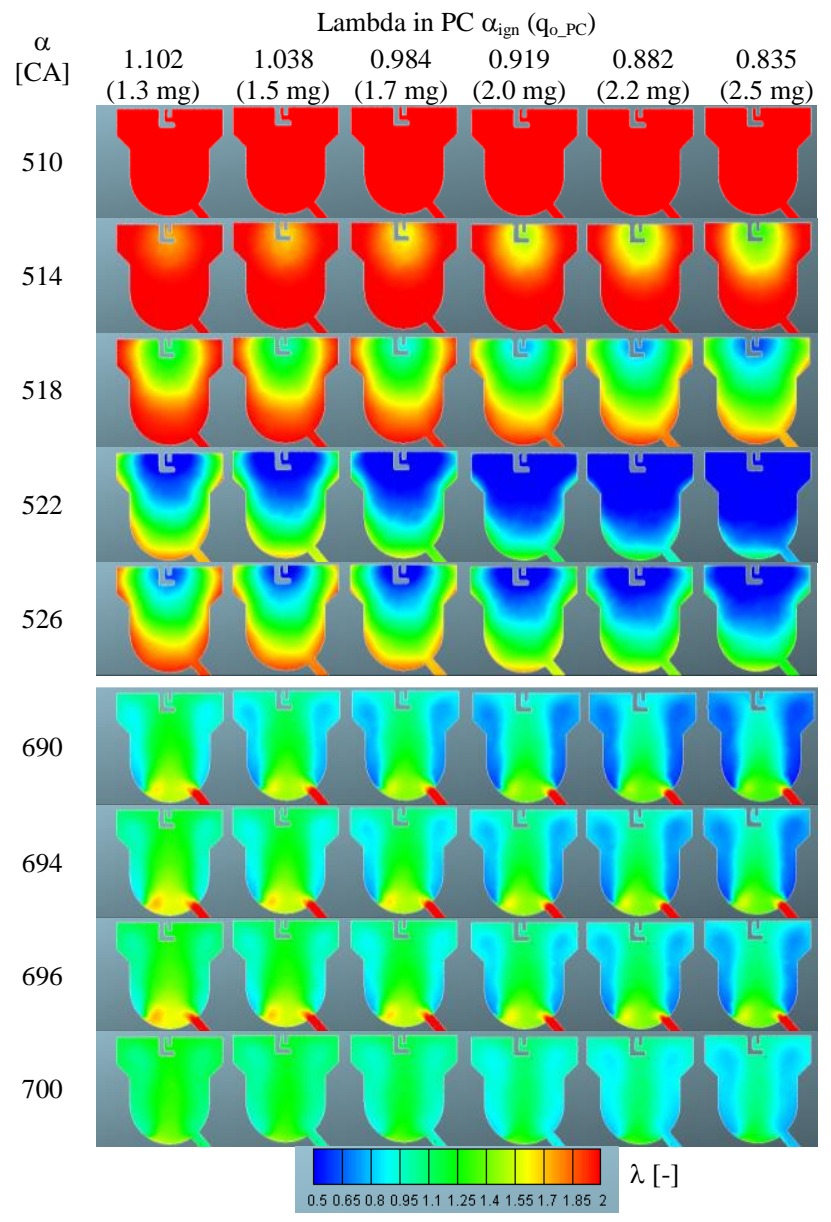

Fig. 6. Air excess ratio in prechamber for different fuel dose values $\mathrm{q}_{\mathrm{o} \_\mathrm{PC}}$

Different values of $\lambda_{\text {PC }}$ resulted in a different combustion process in the prechamber. Mean $\lambda$ values close to the value of 1 mean that the maximum value of the combustion pressure in the prechamber is the lowest (Fig. 7). The highest values of combustion pressure occurred when the fuel

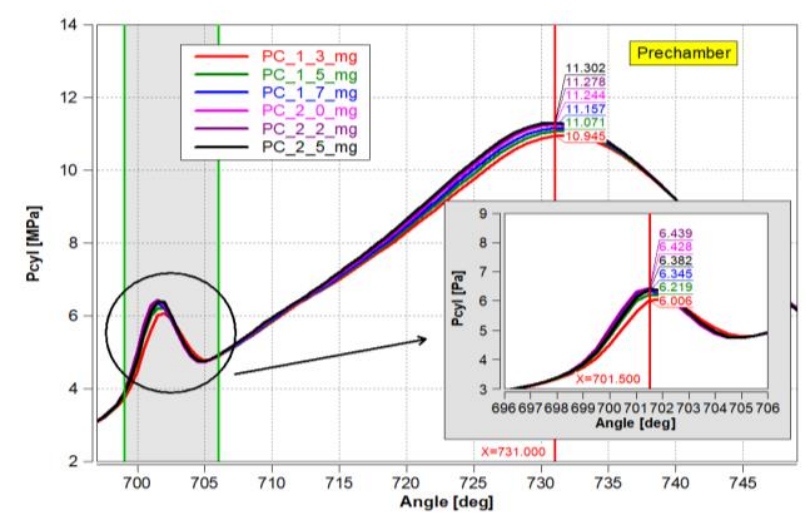

Fig. 7. Combustion pressure characteristic in the prechamber was burned at the value of $\lambda_{\mathrm{PC}}=0.88-0.92$. This means that a mixture that is richer than stoichiometric was more favorable here, which was manifested in the rapid build-up of pressure in the prechamber, but also its rapid termination.

\subsection{Inter-chamber flows}

Confirmation of the limited combustion process at $\lambda_{\mathrm{PC}}=$ $=1.102\left(\mathrm{q}_{\mathrm{o} \_\mathrm{PC}}=1.3 \mathrm{mg}\right)$ is the analysis of inter-chamber flows. At this air excess coefficient value, the flow to the $\mathrm{MC}$ is also the smallest (Fig. 8 - PC_1_3_mg). At an angle of 725 and beyond, the flows were the same.

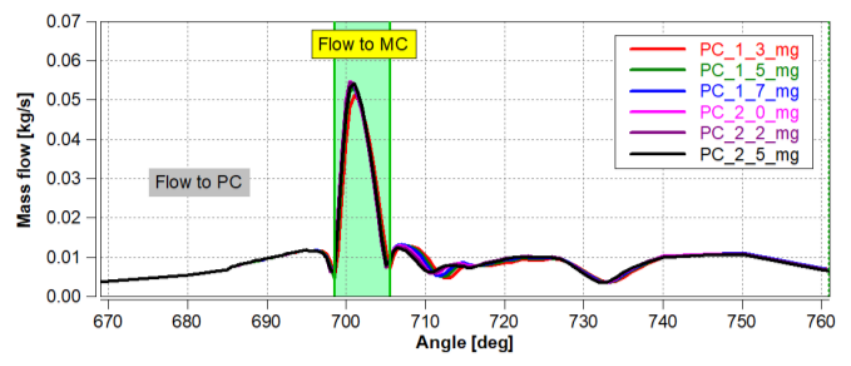

Fig. 8. Inter-chamber flows

The pressure changes in the prechamber during the start of the combustion process were reflected in the obtained maximum pressure values in the PC (around $730 \mathrm{CA}$ ). Combustion at $\lambda=1.102\left(\mathrm{q}_{\mathrm{o} \_\mathrm{PC}}=1.3 \mathrm{mg}\right)$ also resulted in the lowest maximum pressure in the prechamber. Small doses of fuel fed to the prechamber burn with the smallest maximum values occurring in the prechamber.

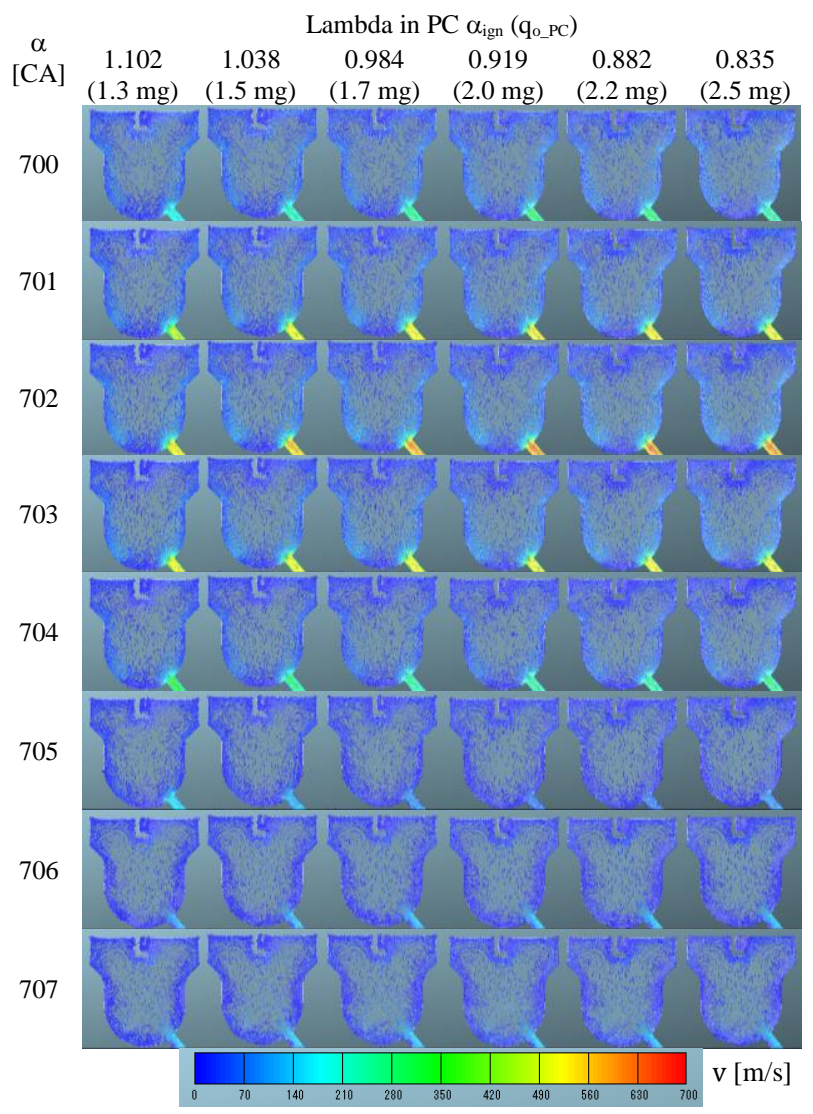

Fig. 9. Impact of the fuel dose fed to the prechamber on the fuel flow rate value between the prechamber and the main chamber 
Spatial analysis of inter-chamber flows (Fig. 9) indicates the existence of the highest flow speeds at $\lambda=0.919$ and at an angle of $702 \mathrm{deg}$. A comparison with Fig. 8 indicates the point of maximum flow. The flow velocity at this angle was about $600 \mathrm{~m} / \mathrm{s}$, however only in the middle of the flow channel. At lower flow rates, the speed is lower, around $150-200 \mathrm{~m} / \mathrm{s}$.

The conditions of inter-chamber flows indicate the existence of an air excess coefficient with a value slightly less than stoichiometric (by about 10\%), which resulted in the combustion process being qualitatively best.

\subsection{Flame development and temperature changes in the prechamber}

The analysis of further combustion process indicators concerns flame development and the related temperature changes. Despite the different combustion process conditions (resulting from different lambda values in the PC), the flame front changes were quite similar (Fig. 10). This means that changes in the $\lambda_{\mathrm{PC}}$ value by about $10-15 \%$ from the stoichiometric value did not significantly affect the changes in the flame front.

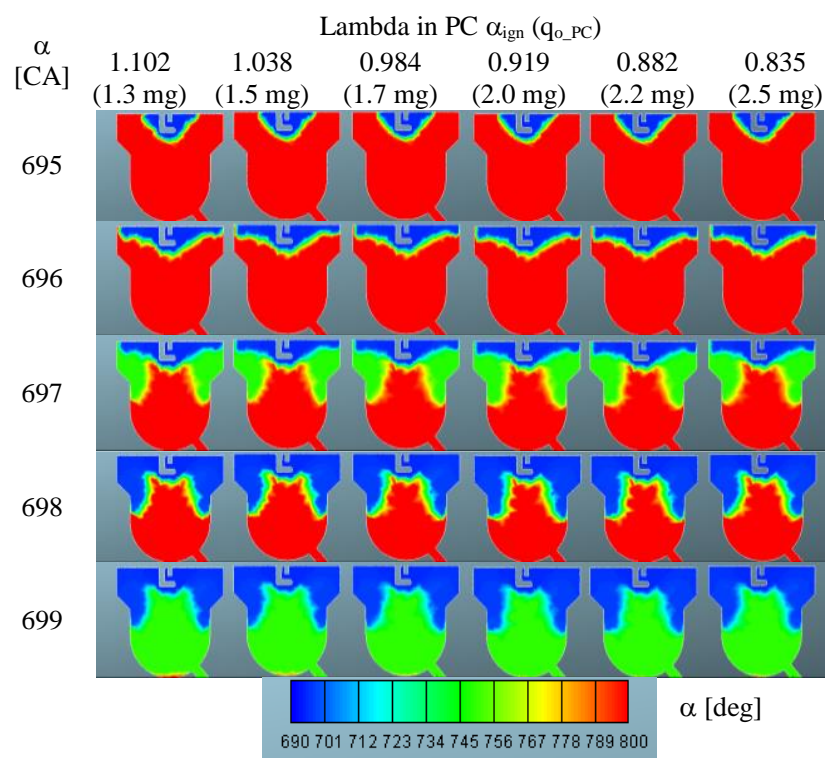

Fig. 10. Flame development (blue area) in the prechamber at different fuel dose values $\mathrm{q}_{\mathrm{o}} \mathrm{PC}$

Although the flame development in the prechamber had a similar character for all test cases, the temperature changes were significant (Fig. 11). Similar ignition delay values resulted from the temperature changes. Rapid temperature rise in the prechamber (at $698 \mathrm{deg}$. CA) had the same character, but the following aspects of the process were different. Small doses administered to the prechamber ( $\lambda$ close to 1) resulted in the lowest temperature values being observed. For the adopted $\mathrm{q}_{\mathrm{o}-\mathrm{PC}}$ values, the temperature changes were about $5 \%$. The temperature characteristic in the prechamber caused the occurrence of a second maximum in the vicinity of the TDC. Here the differences were clearer and amounted to about $7 \%$ - but the nature of the changes was still the same as before. Large $\mathrm{q}_{\mathrm{o} \_\mathrm{PC}}$ fuel doses resulted in the formation of the highest temperature values in the prechamber.

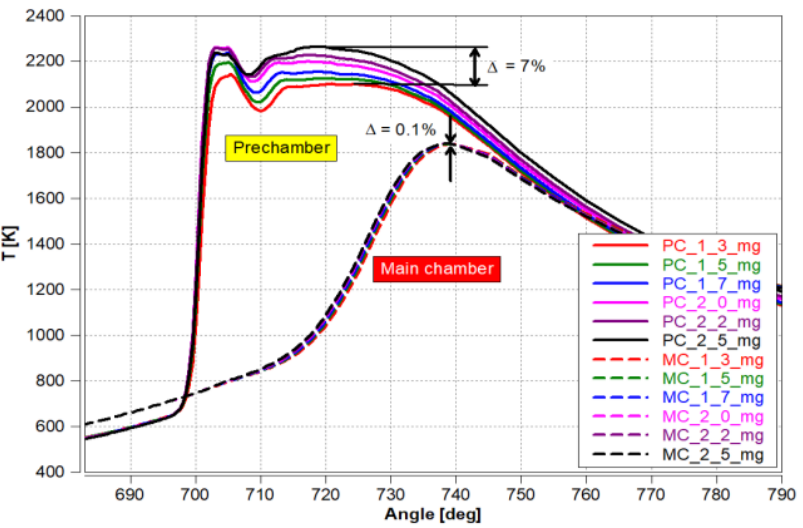

Fig. 11. Combustion temperature changes in the prechamber and in the main chamber

Division of the computational grid into selections allowed an independent determination of the average temperature values in the main chamber. The temperature changes in this part of the cylinder were practically the same (changes in $\mathrm{T}_{\mathrm{mx}}$ were about $0.1 \%$ ). Maximum values observed in the main chamber were about 350-400 K smaller than in the prechamber. Temperature increase in the main chamber was shifted by about $20 \mathrm{deg} \mathrm{CA}$ in relation to the temperature increase in the prechamber.

Analysis of the temperature distribution in the prechamber indicates that the largest temperature values occur around the cylinder walls (Fig. 12). This mirrors the deve-

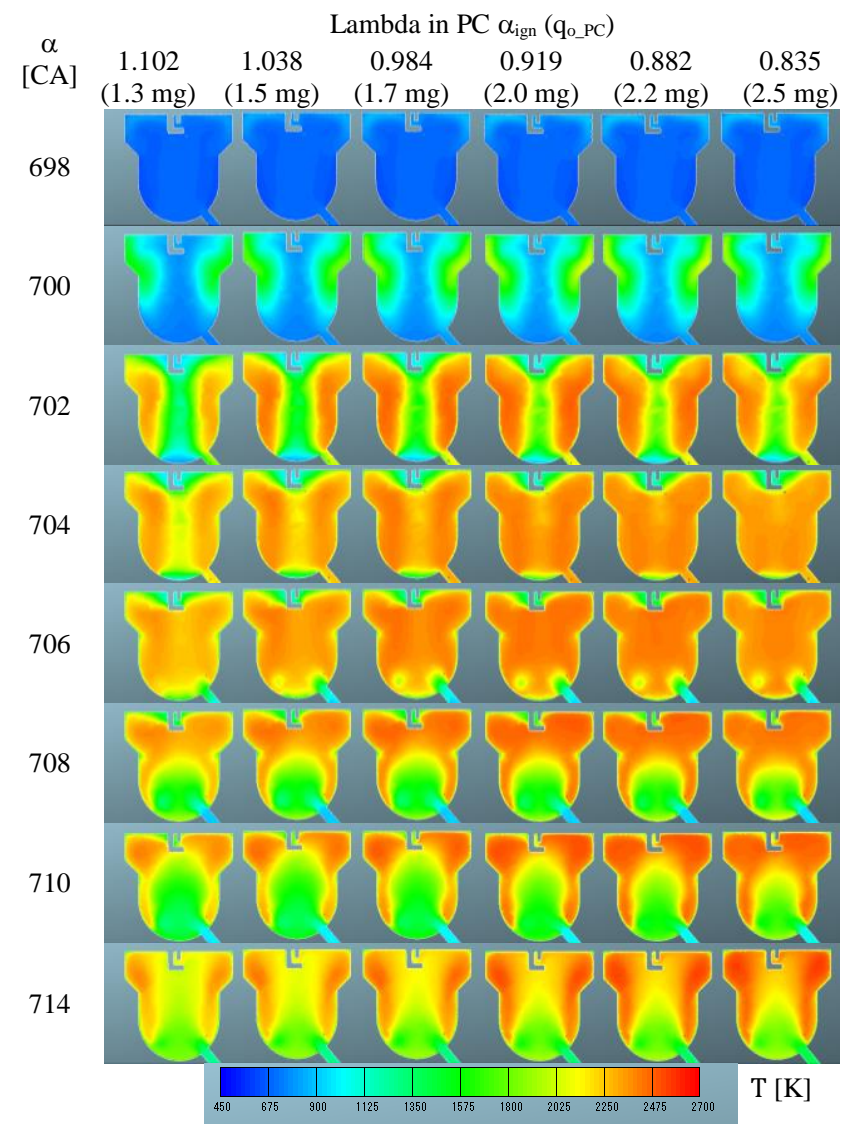

Fig. 12. Temperature changes in the prechamber at different fuel dose values $\mathrm{q}_{\mathrm{o} \_\mathrm{PC}}$ 
lopment of the flame front (Fig. 10). Figure 12 shows that only in a small angular range (about 704 CA) a burning mixture with the largest temperature range (up to $2500 \mathrm{~K}$ ) flows through the cross sections connecting the two chambers.

\subsection{Heat release in combustion chambers}

The heat release rate is determined by the speed of burning the fuel dose mainly in the prechamber. The maximum release rate values increase with the increasing prechamber fuel dose values (Fig. 13). This maximum was reached at $\mathrm{q}_{\mathrm{o} \_\mathrm{PC}}=2.2 \mathrm{mg}$. This means that the maximum increase in qo_PC dose did not lead to an increase in the rate of heat release. Differences between extreme $\mathrm{q}_{\mathrm{o} \_\mathrm{PC}}$ values lead to $18 \%$ HRR changes. Maximum HR changes were smaller but also significant. They amounted to $9 \%$ (the lowest at low doses of qo_PC).

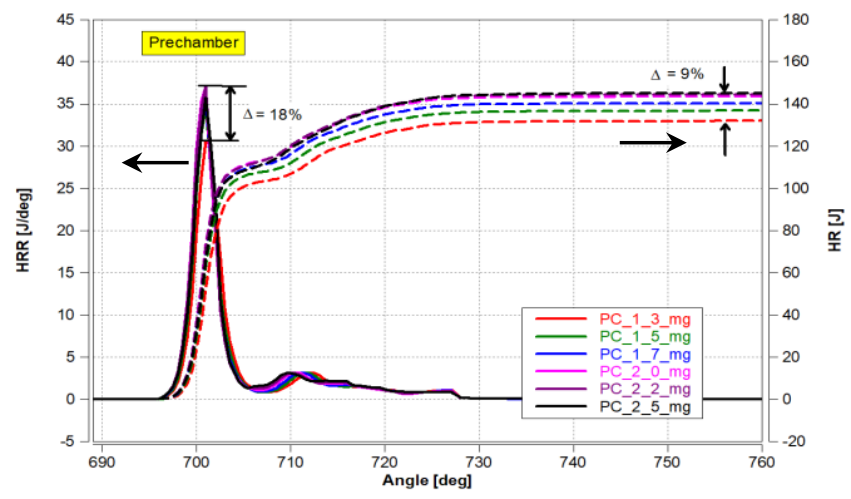

Fig. 13. Changes in HRR and HR in prechamber at different fuel dose values $\mathrm{q}_{\mathrm{o} \_} \mathrm{PC}$

The analysis of HRR and HR in the main chamber indicated no significant differences in the character of changes in these quantities (Fig. 14). The maximum combustion rate values differed by $0.6 \%$, while the maximum values of heat released by only $1 \%$. Combustion efficiency was defined as:

$$
\eta_{\mathrm{c}}=\frac{\mathrm{HR}_{\mathrm{mx}}}{\left(\mathrm{q}_{\mathrm{o} \_} \mathrm{PC}+\mathrm{q}_{\mathrm{o} \_\mathrm{MC}}\right) \cdot \mathrm{LHV}}
$$

where $\mathrm{HR}_{\mathrm{mx}}$ is the maximum of heat release and LHV is the Lower Heating Value of fuel (50 MJ/kg).

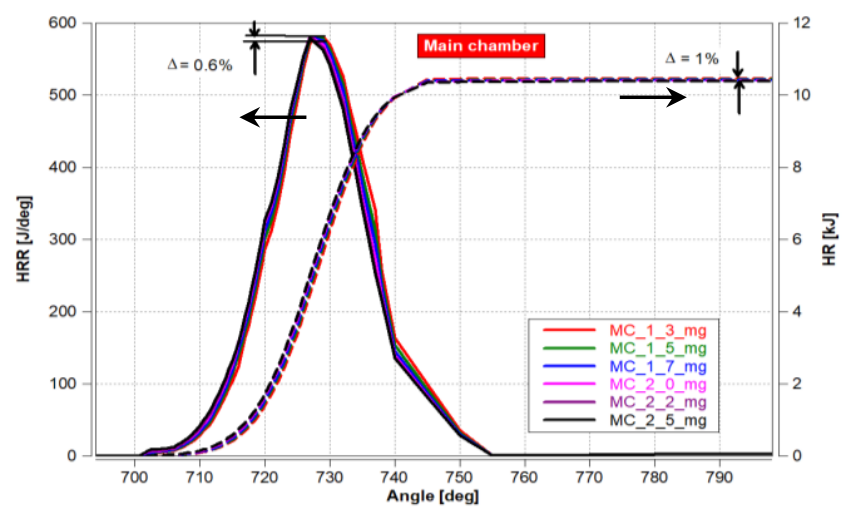

Fig. 14. HRR and HR changes in the main chamber at different fuel dose values $\mathrm{q}_{\mathrm{o}} \mathrm{PC}$
Using the data in Table 2, the above combustion efficiency was determined for the sum of the fuel doses fed to the prechamber and to the main chamber. At the smallest doses of $\mathrm{q}_{\mathrm{o} \_\mathrm{PC}}$ the combustion efficiency was $93.63 \%$, at the highest doses $-92.88 \%$. This means that as the air excess coefficient in the prechamber increases, the combustion efficiency increases as well (but less significantly).

\subsection{Combustion process emission values}

The exhaust emissions evaluation was limited to nitrogen oxides and soot. Both of these values were presented in relation to their mass fraction. The mass fraction of NO in the prechamber at the start of combustion was the highest for a dose close to stoichiometric (Fig. 15). This tendency changes in the following combustion period. A large initial dose produced large amounts of NO, which tended to decrease as $\mathrm{q}_{\mathrm{o}-\mathrm{PC}}$ decreased. The obtained different final NO concentrations reach over $50 \%$.

Soot production behaved differently. With increasing qo_PC its quantity increased - it reached its maximum at $\mathrm{q}_{\mathrm{o} \_\mathrm{PC}}=2.5 \mathrm{mg}$. The soot amount is then $50 \%$ greater than for the minimum dose of $\mathrm{q}_{\mathrm{o} \_P C}$. The advantage of such a combustion system is that the soot concentration, although it appears early in the combustion process, also drops sharply (it burns off) - after TDC its value is only below $5 \%$ of the maximum value (Fig. 15).

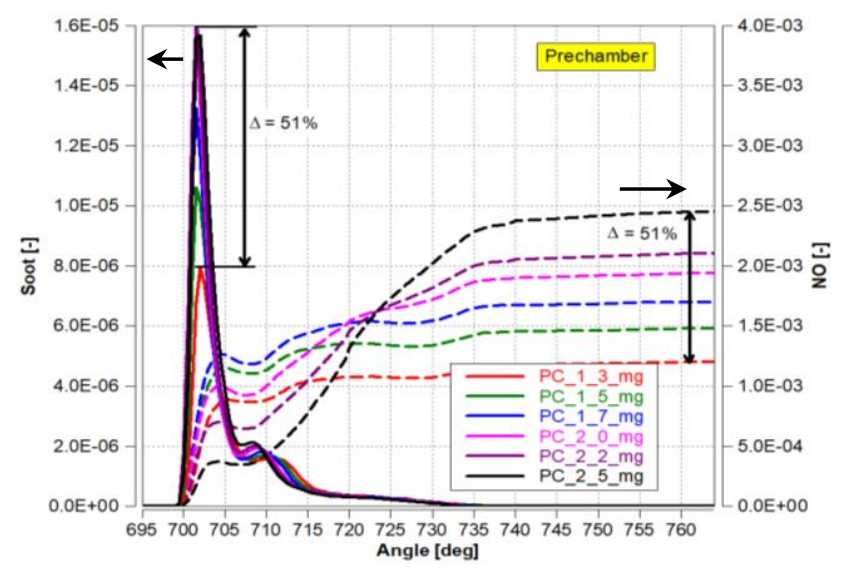

Fig. 15. Changes in NO and soot mass fractions in the prechamber at different fuel dose values $\mathrm{q}_{\mathrm{o} \_} \mathrm{PC}$

The confirmation of the above trends is the spatial analysis of the nitrogen oxides distribution in the prechamber. The highest NO concentration occurred at $\lambda$ close to 1 (Fig. 16) in the initial period of the combustion process. At angles after TDC, the NO concentration was significant when burning large fuel doses in the PC. This indicates a long burning period and persistence of large temperature values in this volume. Maximum NO values occurred locally at large $\mathrm{q}_{\mathrm{o}} \mathrm{PC}$ fuel doses around TDC.

The emissions analysis in the main chamber indicated its similarities regardless of the amount of fuel in the prechamber. This situation applies primarily to soot (change in the maximum value to $4 \%$ ) - Fig. 17. With respect to NO, the changes mainly concern the final part of the process (at an angle above $730 \mathrm{CA}$ ). 


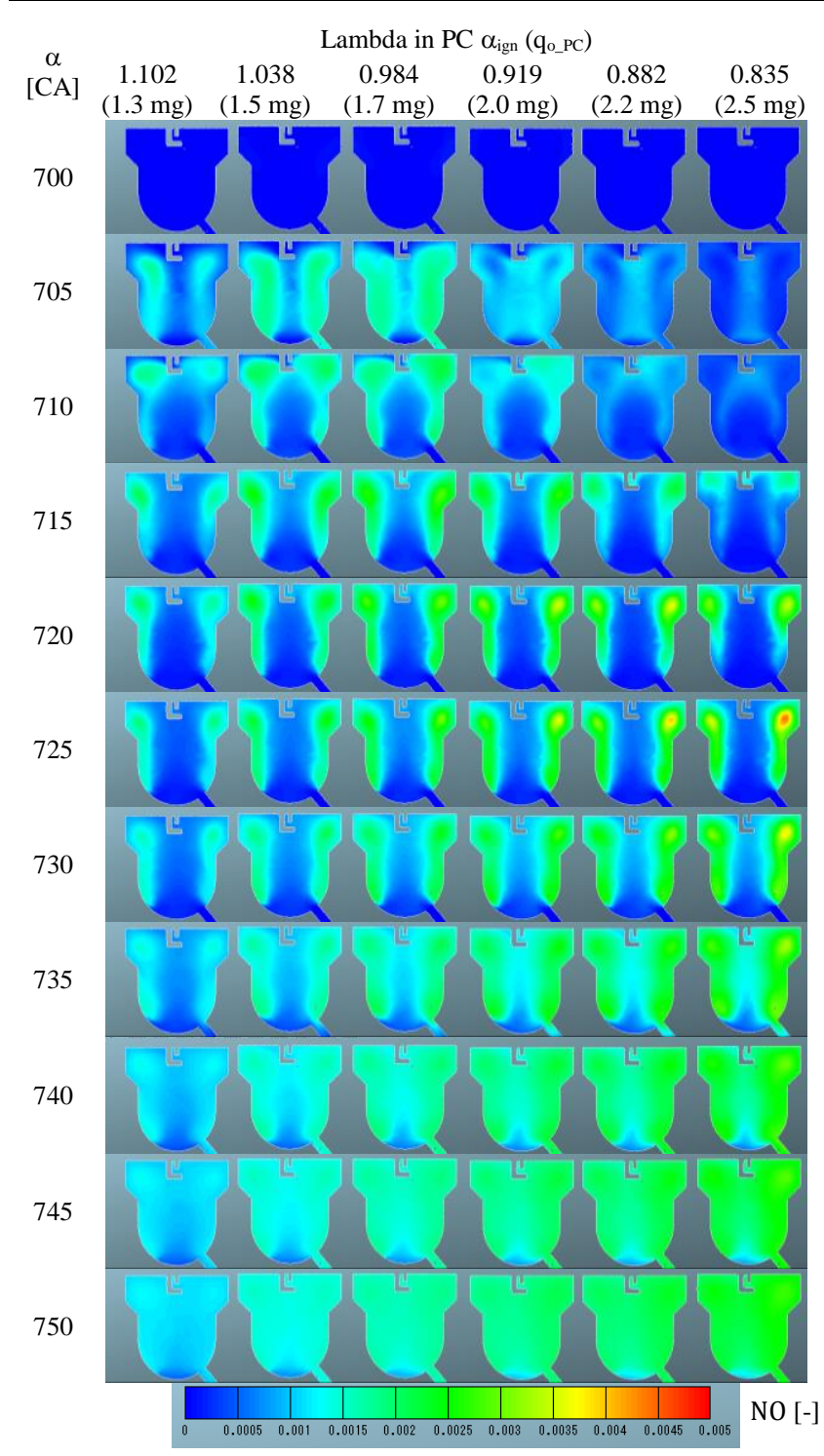

Fig. 16. Impact of the fuel dose fed to the prechamber on the resulting NO mass fraction

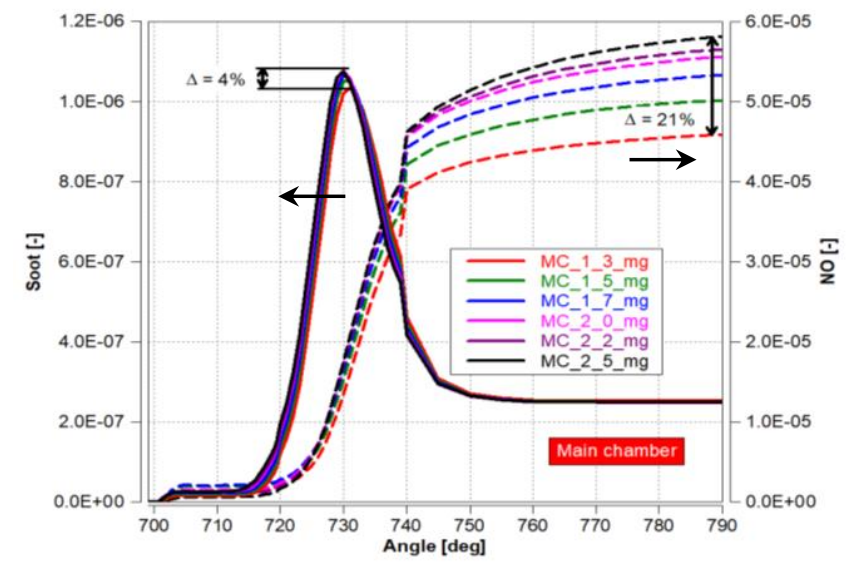

Fig. 17. Changes in NO and soot mass fraction in the main chamber at different fuel dose values qo_PC

The soot concentration is proportional to the fuel dose $\mathrm{q}_{\mathrm{o} \_\mathrm{PC}}$. Soot is formed mainly at the walls of the combustion chamber (even though the fuel is natural gas) - Fig. 18.
When analyzing the formation of NO and soot, it should be stated that soot is formed earlier (insufficient oxidation) in the combustion process than NO. Soot particles appear already at $710 \mathrm{CA}$, while $\mathrm{NO}$ - only at $705 \mathrm{CA}$ (for large fuel doses $\mathrm{q}_{\mathrm{o} \_\mathrm{PC}}$ ). Similar to the mean values (Fig. 15), spatial analysis indicates the dissipation of soot concentration around 705-709 CA. The differences in NO concentration in the prechamber (Fig. 15) and the main chamber (Fig. 17) were mainly due to the air excess ratio. In the prechamber this value is close to one, while in the main chamber the mixture is much leaner. Lower combustion temperature in the initial phase of the process in the main chamber (Fig. 11) also results in lower values of NO formed in this chamber.

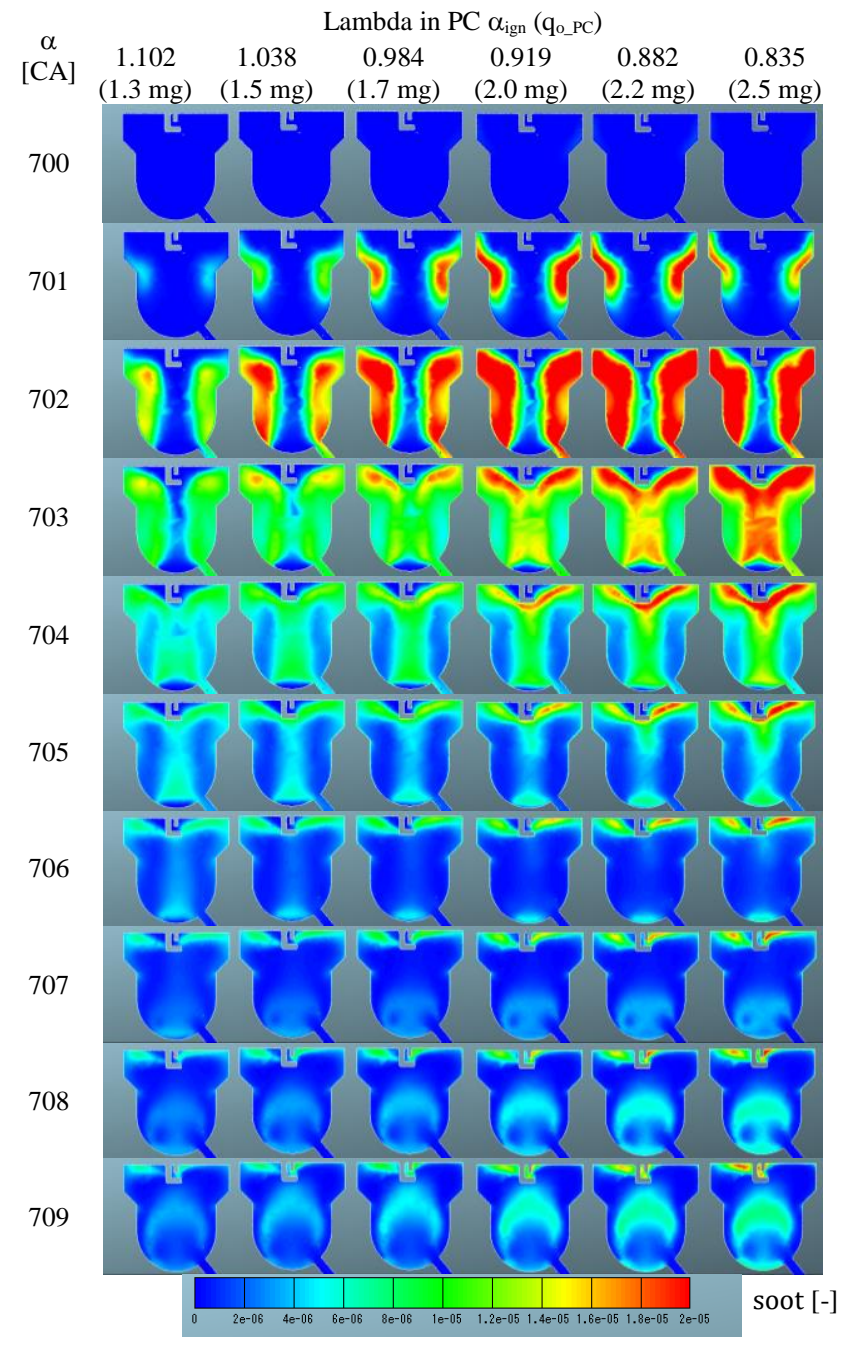

Fig. 18. Influence of the fuel dose fed to the prechamber on the resulting soot mass fraction

\section{Conclusions}

Analysis of thermodynamic processes, in relation to changes in the air excess coefficient value in the prechamber, during the combustion of lean mixtures in HD engines resulted in the following conclusions:

- in relations to combustion process indicators (Fig. 19):

- maximum value of combustion pressure in prechamber during ignition occurs for rich mixtures $(\lambda \approx 0.9)$; 
- the Pmx pressure in the main chamber increases with the decreasing lambda in prechamber (increasing $\mathrm{q}_{\mathrm{o} \_\mathrm{PC}}$ ); the combustion pressure values in both chambers were similar;

- the heat release rate in the prechamber reached its maximum during combustion of stoichiometric mixtures in PC; HRmx is highest at small $\lambda_{\mathrm{PC}}$ (large fuel doses $\mathrm{q}_{\mathrm{o} \_\mathrm{PC}}$;

- slight changes, however, were noted in the main chamber: with increasing $\lambda_{\mathrm{PC}}$ the HRmx also increases;

- the maximum combustion temperature in the PC occurred while burning rich mixtures in it; maximum air excess coefficient values in the MC were around $\lambda=1$

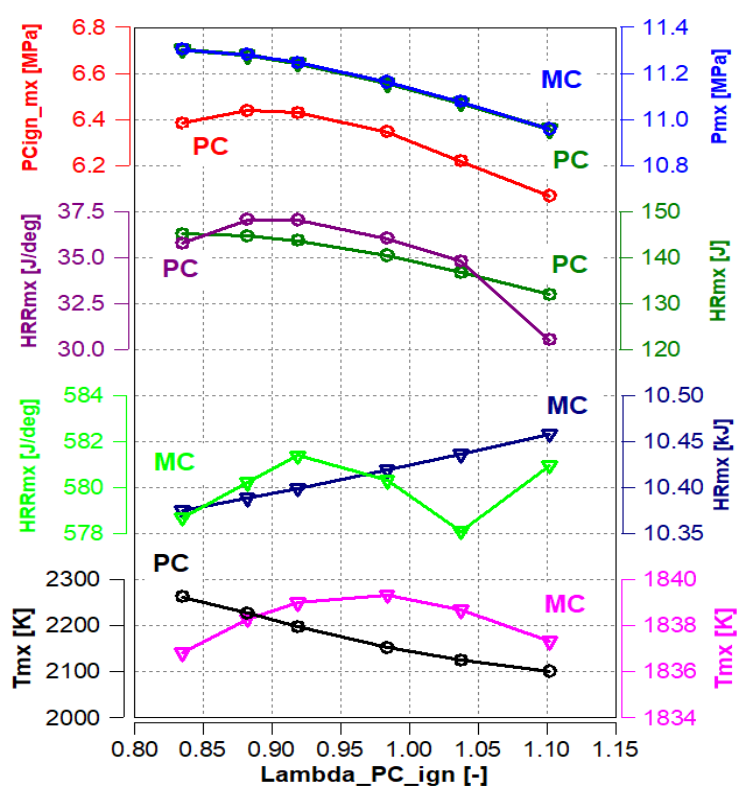

Fig. 19. Changes in combustion process indicators at different air excess ratio at $\mathrm{PC}$ _ign

\section{Nomenclature}

DM Dual Mode

ECFM Extended Coherent Flame Model

HD heavy duty

HR heat release

HRR heat release rate

IMEP indicating mean effective pressure

IVC intake valve closed

LHV Lower Heating Value

MC main chamber

NO nitric oxygen

$\mathrm{P} \quad$ pressure

PC prechamber

PCIS Pre Chamber Ignition System

qo fuel dose

$\mathrm{T}$ temperature

TDC top dead center
- in relations to exhaust emission indicators (Fig. 20):

- maximum mass fraction values in the prechamber occurred when burning rich mixtures; this parameter has a similar characteristic the main chamber; the level of exhaust emissions in the PC is 2 orders higher than in the MC;

- maximum soot values also occurred when burning rich mixtures in both $\mathrm{PC}$ and MC; the soot level in the PC was an order of magnitude higher than in the MC.

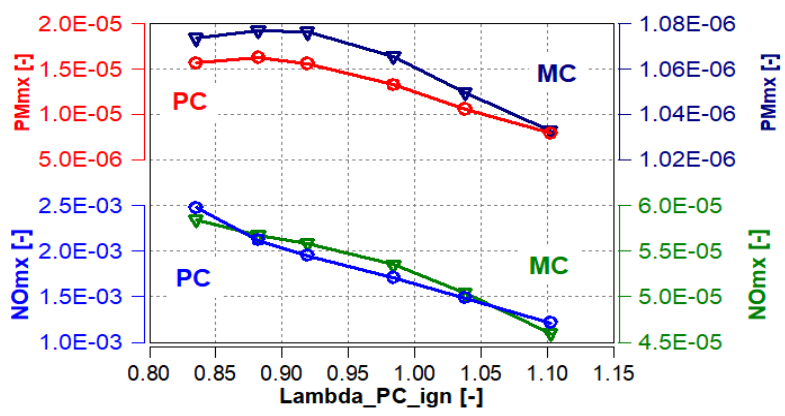

Fig. 19. Changes in NO and soot mass fractions at different air excess ratio at PC_ign

Analysis of the thermodynamic and emission indicators in the tests carried out while feeding the gas engine with a lean mixture at $\lambda=2$ indicates that the most advantageous solution is to use the air excess coefficient value $\lambda=0.9$ -1.0 in the prechamber. For such a solution, the highest thermodynamic indicators of the combustion process were obtained (even though the minimum exhaust emission values were obtained at $\lambda \sim 1.1$ ).

\section{Acknowledgements}

This work has been done under AVL University Partnership Program. 


\section{Bibliography}

[1] AlvareZ, C.E.C., COUTO, G.E., ROSO, V.R. et al. A review of prechamber ignition systems as lean combustion technology for SI engines. Applied Thermal Engineering. 2018, 128, 107-120.

https://doi.org/10.1016/j.applthermaleng.2017.08.118

[2] ATIS, C., CHOWDHURY, S., AYELE, Y. et al. Ultra-lean and high EGR operation of Dual Mode, Turbulent Jet Ignition (DM-TJI) engine with active pre-chamber scavenging. SAE Technical Paper 2020-01-1117. 2020.

https://doi.org/10.4271/2020-01-1117

[3] ATTARD, W.P., FRASER, N., PARSONS, P. et al. A Turbulent Jet Ignition pre-chamber combustion system for large fuel economy improvements in a modern vehicle powertrain. SAE Technical Paper 2010-01-1457. 2010. https://doi.org/10.4271/2010-01-1457

[4] ATTARD, W.P., PARSONS, P. A normally aspirated spark initiated combustion system capable of high load, high efficiency and near zero $\mathrm{NO}_{\mathrm{x}}$ emissions in a modern vehicle powertrain. SAE Technical Paper 2010-01-2196. 2010. https://doi.org/10.4271/2010-01-2196

[5] BUNCE, M., BLAXILL, H. Methodology for combustion analysis of a spark ignition engine incorporating a prechamber combustor. SAE Technical Paper 2014-01-2603. 2014. https://doi.org/10.4271/2014-01-2603

[6] CHINNATHAMBI, P., BUNCE, M., CRUFF, L. RANS based multidimensional modeling of an ultra-lean burn prechamber combustion system with auxiliary liquid gasoline injection. SAE Technical Paper 2015-01-0386. 2015. https://doi.org/10.4271/2015-01-0386

[7] COLIN, O., BENKENIDA, A. The 3-Zones Extended Coherent Flame Model (ECFM3Z) for computing premixed/diffusion combustion. Oil\&Gas Science and Technology - Rev. IFP. 2004, 59(6), 593-609.

https://doi.org/10.2516/ogst:2004043

[8] COLIN, O., BENKENIDA, A., ANGELBERGER, C. A 3D modeling of mixing, ignition and combustion phenomena in highly stratified gasoline engines. Oil\&Gas Science and Technology - Rev. IFP. 2003, 58(1), 47-62. https://doi.org/10.2516/ogst:2003004

[9] DA COSTA, R.B.R., TEIXEIRA, A.F., FILHO, F.A.R. et al. Development of a homogeneous charge pre-chamber torch ignition system for an SI engine fuelled with hydrous ethanol. Applied Thermal Engineering. 2019, 152, 261-274. https://doi.org/10.1016/j.applthermaleng.2019.02.090
[10] GARG, M., RAVIKRISHNA, R.V. In-cylinder flow and combustion modeling of a CNG-fuelled stratified charge engine. Applied Thermal Engineering. 2019, 149, 425-438. https://doi.org/10.1016/j.applthermaleng.2018.12.036

[11] GIANETTI, G., SFORZA, L., LUCCHINI, T. et al. CFD modeling of combustion of a natural gas light-duty engine. Energy Procedia. 2018, 148, 954-961. https://doi.org/10.1016/j.egypro.2018.08.067

[12] HUA, J., ZHOU, L., GAO, Q. et al. Effects on cycle-tocycle variations and knocking combustion of Turbulent Jet Ignition (TJI) with a small volume pre-chamber. SAE Technical Paper 2020-01-1119. 2020. https://doi.org/10.4271/2020-01-1119

[13] KORB, B., KUPPA, K., NGUYEN, H.D. et al. Experimental and numerical investigations of charge motion and combustion in lean-burn natural gas engines. Combustion and Flame. 2020, 212, 309-322. https://doi.org/10.1016/j.combustflame.2019.11.005

[14] Mitsubishi Turbocharger and Engine Europe B.V. Gas engine GS16R2-PTK. https://www.mtee.eu/news/403/introducing-new-gs16r2-ptk

[15] NEUMANN, S., BIENWALD, M., HERDIN, G. Prechamber pressure-based management of gas engines. MTZ Industry. 2016, 6, 58-63. https://doi.org/10.1007/s40353016-0011-9

[16] NOVELLA, R., PASTOR, J., GOMEZ-SORIANO, J. et al. Experimental and numerical analysis of passive pre-chamber ignition with EGR and air dilution for future generation passenger car engines. SAE Technical Paper 2020-01-0238. 2020. https://doi.org/10.4271/2020-01-0238

[17] PIELECHA, I., BUESCHKE, W., SKOWRON, M. et al. Prechamber optimal selection for a two stage turbulent jet ignition type combustion system in CNG-fuelled engine. Combustion Engines. 2019, 176(1), 16-26. https://doi.org/10.19206/CE-2019-103

[18] ROSO, V.R., SANTOS, N.D.S., VALLE, R.M. et al. Evaluation of a stratified prechamber ignition concept for vehicular applications in real world and standardized driving cycles. Applied Energy. 2019, 254, 113691. https://doi.org/10.1016/j.apenergy.2019.113691

[19] SENS, M., BINDER, E. Pre-chamber ignition as a key technology for future powertrain fleets. MTZ Worldwide. 2019, 80, 44-51. https://doi.org/10.1007/s38313-018-0150-1

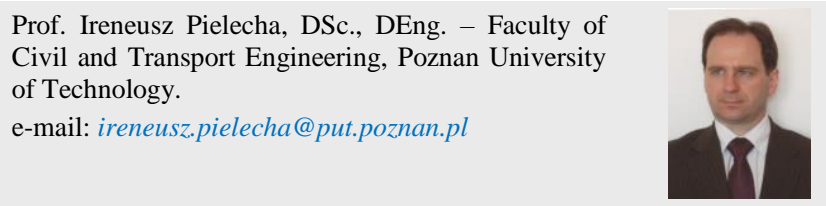

